TLO

$11,4 / 5$

332

\section{Intellectual capital in Egyptian software firms}

\author{
Ahmed Seleim and Ahmed Ashour \\ Alexandria University, Alexandria, Egypt \\ Nick Bontis
}

DeGroote School of Business, McMaster University, Hamilton, Ontario, Canada

Keywords Egypt, Intellectual capital, Human capital, Computer software

\begin{abstract}
The distribution of knowledge around the world varies significantly with developed countries possessing most of the world's current intellectual capital (IC) compared to developing countries. Most IC research has been conducted in a variety of international settings such as the UK, Scandinavia, Australia, Canada, Austria, Malaysia, the USA, and Ireland. However, no empirical research has been conducted at the organizational level in the field of IC in Arab countries. These nations are socially, economically, and culturally different from most countries in the aforementioned list. This study describes the IC in Egyptian software firms. The study's objective is to contribute to the IC theory development by building a measurement system in an unique context. This paper highlights the key IC indicators as reported by Egyptian CEOs. Ultimately, the resultant report provides them with a direction for building a strong knowledge base for future IC development.
\end{abstract}

\section{Introduction}

With the emergence of the knowledge-based economy, we have witnessed many changes in the nature of work and the demands placed on organizations to become the storehouses of innovation, nourishing and sustaining wellsprings of talent. The knowledge-based economy has provided us with new notions of globalization (i.e. borderless economies) and new models for firms (i.e. networked learning organizations). These emergent trends have a great influence on management research and require new approaches for investigation. Over four decades back, Penrose (1959) looked at the firm as a repository of knowledge and experience and argued that knowledge is the critical factor in explaining the growth of firms. More recently, intellectual capital (IC) is considered as the critical antecedent for the sustained performance of a firm (Bierly and Chakrabarti, 1996; Bontis, 1996, 1998, 1999, 2001, 2003; Brennan and Connell, 2000; Grant, 1996; Kogut and Zander, 1992; Spender, 1996). Indeed, some have gone farther to say that knowledge assets have become more important to business success than the traditional factors of production (Choo and Bontis, 2002; Drucker, 1993; Edvinsson and Malone, 1997; Stewart, 1997; Sveiby, 1997). In this new paradigm, IC consists of three components: human capital, structural capital, and relational capital (Bontis, 1999, 2001; Edvinsson and Malone, 1997; Nahapiet and Ghoshal, 1998; Petty and Guthrie, 2000; Sveiby, 1997). Stewart (1997) defines IC as intellectual material - knowledge, information, intellectual property and experience - that can be put to use to create wealth. Thus, IC is the possession of knowledge, applied experience, organizational technology, customer relationships, and professional skill that provide a competitive edge in the market (Edvinsson and Malone, 1997). IC also captures both stocks and flows of an organization's overall knowledge base (Bontis, 1999; Bontis et al., 2002).
The Learning Organization Vol. 11 No. $4 / 5,2004$ pp. $332-346$ (C) Emerald Group Publishing Limited 0969-6474

DOI $10.1108 / 09696470410538233$ 
Based on the notion that "what is measured, is managed", the measurement of IC becomes critically important for firms in the knowledge-based era. There are many frameworks that attempt to measure the IC including the Balanced Scorecard (Kaplan and Norton, 1992), the IC Navigator (Edvinsson and Malone, 1997), the Intangible Assets Monitor (Sveiby, 1997), and others (Bontis, 2001; Bontis et al., 1999 for a comprehensive review). Most of the historical research in the field concentrates on examining the relationship between the IC and performance (Ashour, 2000; Bontis, 1998, 1999; Bontis and Fitz-enz, 2002; Brennan and Connell, 2000; Brooking, 1997; Bontis, et al., 2000; Chase, 1997; Guthrie and Petty, 2000; Harrison and Sullivan, 2000; Hussi and Ahonen, 2002; Joia, 2000; Marques and Garrigos, 2003; Roos and Roos, 1997). This study attempts to describe the IC by examining both stocks and flows of knowledge resources. It aims to generate specific hypotheses that link IC components with organizational performance within an Egyptian software firm context.

\section{Focus of study}

Brennan and Connell (2000) summarize 14 empirical research studies on different aspects of IC. Their research shows that a variety of data collection methodologies were used including interview, case study, questionnaire, survey of annual reports and focus groups. The most popular method was examining the case studies across a small number of companies. However, interviews and questionnaires were often used to supplement each other and usually involved larger sample sizes offering stronger empirical support. Following this, the authors decided to conduct a cross-sectional field survey across Egyptian software firms in order to further develop the empirical support for IC and to provide an unique context that has not been studied earlier.

The present study involves three groups of variables: human capital, structural capital and relational capital. Human capital refers to a combination of indicators that reflect the individual talent in the firm and the renewal and development of its human resources. Human capital is the sum of the workers' skills, experience, capabilities, and innate knowledge (Edvinsson and Malone, 1997). Moreover, Bontis (1998) describes human capital as the firm's collective capability to extract the best solutions from the knowledge of its individuals. Structural capital focuses on the codified knowledge base of the firm. It is often referred to as what is left when employees go home at night (Roos et al., 1997). Structural capital also reflects the firm's ability to translate the innovation and energy of its human capital into company property while capitalizing on that innovation to create wealth. Relational capital reflects the ability of the firm to interact positively with business community members in order to stimulate potential for wealth creation by enhancing human and structural capital. It includes all knowledge assets accumulated by the firm from its relationships with customers and other partners, competitors, associations, governments, or other organizations that interact with the firm (Bontis, 1999).

\section{Sample and measures}

The target population for the study was all the 107 member firms of the Software Industry Chamber in Egypt. The final sample consists of 38 software firms representing 35.5 percent of the total population. Table I represents the distribution of the sample. 


\section{TLO \\ $11,4 / 5$}

\begin{tabular}{llrr} 
& Firm size (\# of employees) & & 13 \\
& $<10$ & 5 & 42 \\
$\mathbf{3 3 4}$ & $10-50$ & 16 & 32 \\
& $51-100$ & 12 & 8 \\
& $101-200$ & 3 & 3 \\
& $201-300$ & 1 & 3 \\
& $>300$ & 1 & 3 \\
& Firm age (\# of years) & 1 & 45 \\
& $<3$ & 17 & 32 \\
& $3-5$ & 12 & 21 \\
& $6-10$ & 8 & 37 \\
& $>10$ & 14 & 53 \\
Table I. & Type of firm & 20 & 8 \\
Sample descriptive & Individual ownership & 3 & 68 \\
statistics & Corporation & 26 & 11 \\
& Branch for international firm & 4 & 21 \\
\hline
\end{tabular}

The software industry is an excellent setting to understand the features of the knowledge-based economy. Generally speaking, software firms lack tangible assets and face a rapid obsolescence of products more so than the firms in other sectors. The industry is characterized by a high degree of product innovations and provides markets with several products.

The Egyptian software industry is facing burgeoning growth with export sales totalling 50 million USD within a total market estimated at 140 million USD (as reported in an interview with the president of the Egyptian Software Industry Chamber). Furthermore, Egypt has thousands of qualified software professionals and has become a major supplier of software products and services to neighbouring countries in the Arab region (Arab Human Development Report, 2002).

The measurement of IC components has been the subject of considerable debate by several academics and practitioners (Bontis, 1999; Dooley, 2000; Youndt, 1998). For example, Liebowitz and Suen (2000) report that existing metrics do not distinguish among input, output, and processes of IC. Moreover, some measurement frameworks do not include the flow dimension of IC. Ultimately, knowledge assets cannot be measured directly. They must be measured indirectly by measuring elements that are known to relate to these items. The IC used in the present study are based on the numbers and ratios that focus on the amount or quality of the knowledge assets or the use of such assets, and or the actions and practices to improve these assets. Other indicators have been added to this list by authors based on the pilot study and the opinions of some experts in the field of software firms in Egypt.

A list of the used indicators is classified under the three main IC components. Human capital measures include indicators such as: number of certified developers, superstar developers (their performance equals four times the performance of their colleagues), star developers (their performance equals two times the performance of their 
colleagues), new comers, leaving developers, developers who attended project management training programs, developers who are able to translate customer needs into programming structures, developers who have the ability to work in a team, training hours for developers, years of experience, and level of software developer talent.

Structural capital measures include indicators such as: number of books and references in the company library, number of licenses from international companies, number of meetings held among the developers weekly, percentage of implementing software project documentation, percentage of reusability of knowledge from previous projects, average number of bugs in a system or program, percentage of using prototype in software development, number of registered system programs, number of unregistered system programs, and implementation speed for projects within the company and the number of innovation sources in developing software.

Relational capital measures include indicators such as: percentage of long-term customers, average time from customer complaint to solution delivery for that complaint, how many customers participate in software testing before final delivery, percentage of customers who regularly upgrade or buy the follow product, percentage of software launched by the release date, customer's complaints, percentage of positive media PR in achieving business goals, number of connections and correlates between the company and the research centers and universities, how many times the media write about the company, number of talks in conference sessions about the company, number of memberships in association or professional organizations, number of countries the company exports to and the number of collaborative ventures with competitors.

\section{Data collection}

A letter was sent by fax, e-mail, and regular mail to the head of each company accompanied by a recommendation letter from the head of the Management Department at Alexandria University to encourage each company to participate in the study. Some of them requested a copy of the questionnaire before deciding to participate. Other firms refused to participate in the study because of the confidentiality of the required data. The companies that agreed to participate in the study made an appointment to the researcher to visit the company. The original intent was to calculate the selected items from data and information that could be obtained from public annual reports, balance sheets and other sources. Unfortunately, due to the confidentiality of some of the required items, some measures were collected through the self-reported questionnaire completed by the CEO. The questionnaire asked the $\mathrm{CEO}$ or one of their knowledgeable representatives in the participating firms to provide his or her estimation about the elements of IC included in the study. The questionnaire and interviews were conducted in Arabic. The whole interview process took between 2 and $4 \mathrm{~h}$ to complete.

\section{Results}

Table II shows the results of the data collected.

\section{Human capital indicators}

On an average, each firm sampled had approximately 43 employees. The results show that the average number of certified developers was 5.89 per firm. While the maximum

\section{Intellectual \\ capital}

335 


\section{TLO \\ $11,4 / 5$}

\begin{tabular}{|c|c|c|c|c|}
\hline & Mean & $\mathrm{SD}$ & Min & Max \\
\hline \multicolumn{5}{|l|}{ Human capital } \\
\hline Certified developers & 5.89 & 5.88 & 0 & 25 \\
\hline Superstar developers & 7.60 & 7.10 & 1 & 30 \\
\hline Star developers & 8.94 & 10.26 & 0 & 40 \\
\hline Newcomers & 7.42 & 8.85 & 0 & 50 \\
\hline Leaving developers & 2.65 & 2.35 & 10 & 0 \\
\hline $\begin{array}{l}\text { Developers attended project management } \\
\text { training program }\end{array}$ & 5.21 & 9.39 & 0 & 55 \\
\hline $\begin{array}{l}\text { Developers translate customer needs } \\
\text { into programming }\end{array}$ & 6.39 & 5.84 & 30 & 1 \\
\hline $\begin{array}{l}\text { Developer who have the ability to work } \\
\text { in a team }\end{array}$ & 17.63 & 16.98 & 70 & 2 \\
\hline Training hours for developers & 111.86 & 55.82 & 240 & 30 \\
\hline Years of experience & 6.39 & 3.66 & 20 & 2 \\
\hline Level of software developer talent & 4.44 & 0.60 & 3 & 5 \\
\hline \multicolumn{5}{|l|}{ Structural capital } \\
\hline $\begin{array}{l}\text { Number of books and references in the } \\
\text { company library }\end{array}$ & 165 & 222 & 5 & 900 \\
\hline Number of licenses from international companies & 6 & 13 & 0 & 70 \\
\hline $\begin{array}{l}\text { Number of meetings held among } \\
\text { developers weekly }\end{array}$ & 2.5 & 2.5 & 1 & 12 \\
\hline Percentage of implementing software project & & & 30 & 100 \\
\hline Percentage of the reusability of knowledge & 88 & 20 & 30 & 100 \\
\hline from previous projects (percent) & 80 & 22 & 20 & 100 \\
\hline $\begin{array}{l}\text { Average number of bugs in a system or } \\
\text { program (percent) }\end{array}$ & 0.8 & 0.7 & 0 & 3 \\
\hline $\begin{array}{l}\text { Percentage of using prototype in software } \\
\text { development (percent) }\end{array}$ & 59 & 31 & 0 & 100 \\
\hline Number of registered system programs & 23 & 74 & 0 & 450 \\
\hline Number of unregistered system programs & 6 & 10 & 0 & 40 \\
\hline $\begin{array}{l}\text { Implementation speed for projects within } \\
\text { the company }\end{array}$ & 3.89 & 0.68 & 3 & 5 \\
\hline Number of firms with ISO certification & 11 & & & \\
\hline Number of firms with CMM certification - Level 0 & 36 & & & \\
\hline Percentage of firms with CMM certification - & & & & \\
\hline Level 1 & 2 & & & \\
\hline \multicolumn{5}{|l|}{ Relational capital } \\
\hline Percentage of long-term customers (percent) & 80 & 16 & 30 & 100 \\
\hline $\begin{array}{l}\text { Average days from customer complaint to } \\
\text { solution delivery }\end{array}$ & 2.94 & 4.19 & 0.04 & 24 \\
\hline $\begin{array}{l}\text { Customers who participate in testing before } \\
\text { final delivery }\end{array}$ & 9.92 & 19.66 & 0 & 100 \\
\hline $\begin{array}{l}\text { Percentage of customers who regularly } \\
\text { upgrade (percent) }\end{array}$ & 42 & 31 & 0 & 100 \\
\hline $\begin{array}{l}\text { Percentage of software launched by the release } \\
\text { date (percent) }\end{array}$ & 85 & 11 & 50 & 100 \\
\hline Percentage of customer complaints (percent) & 14 & 8 & 2 & 25 \\
\hline
\end{tabular}

336

Table II.

Description of IC indicators

uman capital

Certified developers

Superstar developers

Developers attended project management

training program

in a team

Training hour

Years of experience

Level of software developer talent

tructural capital

Number of books and references in the

company library

Number of licenses from international companies

ings held among

developers weekly

documentation (percent)

Percentage of the reusability of knowledge

(percent)

Average number of bugs in a system or

development (percent)

Number of registered system programs

Number of unregistered system programs

Number of firms with ISO certification

Number of firms with CMM certification - Level 0

Percentage of firms with CMM certification -

elational capita

Percentage of long-term customers (percent)

Average days from customer complaint to

solution delivery

Percentage of customers who regularly

Percentage of software launched by the release

date (percent)

indicators 


\begin{tabular}{|c|c|c|c|c|c|}
\hline & Mean & $\mathrm{SD}$ & Min & Max & Intellectual \\
\hline $\begin{array}{l}\text { Percentage of positive media PR in achieving } \\
\text { business goals (percent) }\end{array}$ & 55 & 31 & 0 & 100 & \\
\hline $\begin{array}{l}\text { Number of connections between the company } \\
\text { and the experts }\end{array}$ & 3.52 & 3.93 & 0 & 20 & \\
\hline $\begin{array}{l}\text { How many times the media write about } \\
\text { the company }\end{array}$ & 8.94 & 10.55 & 0 & 50 & 337 \\
\hline $\begin{array}{l}\text { Number of talks in conference and sessions } \\
\text { about the company } \\
\text { Number of memberships in association or }\end{array}$ & 1.68 & 1.64 & 0 & 8 & \\
\hline pro organizations & 4.13 & 3.82 & 0 & 20 & \\
\hline Number of countries the company exports to & 8.81 & 13.75 & 0 & 80 & \\
\hline Number of collaborative ventures with competitors & 1.31 & 1.14 & 0 & 5 & Table II. \\
\hline
\end{tabular}

was 25 and the minimum was 0 , the average is relatively low. According to Lapierre and McKay (2002) professional or technical competencies in particular job families such as accounting, auditing and software development are critical. Furthermore, accreditation of human capital through professional certificates plays an integral role in software development. In a recent study, Roberts (2002) reports that Oracle and Check Point Software Technologies certifications offer the highest rate of return for smaller solution providers, while Compaq Computer and Oracle certifications offer the best ROI for larger solution providers. Thus, the number of certified developers is an adequate proxy for the quality of human capital in a software firm. The results also show that the average number of superstar developers was 7.6 per firm and the average number of star developers was 8.9 per firm. The three aforementioned indicators are considered stocks of human capital as they represent the volume of investment by the firm in its effort to recruit qualified developers. These results confirm what has been reported by some scholars who argue that knowledge required for scientific discovery is embodied in a few specific individuals (Zucker et al., 1998).

The average number of newcomers was 7.4 employees per firm. This indicator presents a kind of positive flow to the stocks of the human capital. The newcomers constitute a kind of increase to the genetic and inheritance map in the firm. New employees typically bring new ideas and different experiences to be added to the existing stock of human capital. New developers are hired so that they may bring improvements to the knowledge discovery of the firm. On the other hand, the average number of developers who left annually was 2.7 per firm. The overall turnover rate for software developers was calculated for the purpose of comparing the Egyptian firms with their international counterparts. The turnover rate for Egyptian software developers was 10.5 percent. This ratio was calculated by dividing the number of leaving developers to the total number of developers in the whole sample. The international turnover rate for software developers is 21 percent. The explanation for the relatively lower rate of turnover for software developers in Egypt is the higher rate of unemployment of the country. Higher unemployment affects the mobility of software developers. Also, the majority of the software firms in Egypt are family-owned businesses which are characterized by a high level of emotional capital which plays a major role in determining the stability of the organizations. Moreover, 
TLO $11,4 / 5$

338 one can explain the lower rate of turnover by appreciating the relatively short age of the software industry in Egypt in general. Nevertheless, turnover has dual effects on IC. Some studies indicate that staff turnover is the main cause of the loss of institutional memory (Mason and Pauleen, 2003) as well as loss of organization level tacit knowledge (Stovel and Bontis, 2002). Conversely, other research findings show that employee turnover sometimes reduces stagnation and improves innovation (Abelson and Baysinger, 1984) while separating poor performers (Dalton and Todor, 1979).

The average number of developers who received training in project management was 5.21 developers per firm while 6.39 developers could translate customer needs into programming. Both these ratios are considered low given the importance of project management training in software development and client customization and both these indicators represent stocks of human capital in the firm. The average number of total training hours (including on the job training or informal training) for developers in the sample was $111 \mathrm{~h}$ per firm or approximately 14 training days per employee per firm per year. This indicator is considered as a positive knowledge flow because learning processes are necessary to renew human capital. These results confirm reports about the importance of emphasizing the investment in IC to provoke further complementary investments, producing a self-feeding circle of investment and value creation (Stewart, 1997).

Results also show that the average number of developers who are able to work in a team was 17.6. This ratio is also low regarding the importance of teamwork in software development. This indicator has a great influence on the building of human capital because it is one of the important mechanisms for collective learning and knowledge exchange among team members. Socialization is a basic mechanism for the transfer of tacit knowledge embedded in experiences.

The average length of experience for developers was 6.4 years. The sample ranged from 2 to 20 years. The average years of experience is considered reasonable in light of the relatively short age of the software industry in Egypt. Tenure is a basic component of the stock of human capital in organizations (Edvinsson and Malone, 1997).

The value of the level of talent among the developers is 4.4 which is considered high. Talent level was measured using a five-point Likert-type scale with values ranging from 1 (very low) to 5 (very high). Also, the relatively low standard deviation score of 0.6 reflects that the variation among the CEOs concerning the level of talent on the firm level was low. Talent level is considered as one of the most important elements of human capital stock which is a prime source of competitive advantage.

Based on the aforementioned results, one can argue that Egyptian software firms possess many elements of human capital. Therefore, the following research proposition is suggested.

P1. There is a positive association between the human capital indicators and organizational performance.

\section{Structural capital indicators}

Results show that there was an average of 165 books in each firm's library. Scientific and professional references are one codified source of structural capital in knowledge intensive firms because they contain information that can be harvested for software development. Codified knowledge documents constitute a flow of knowledge in that 
they add to the stocks of human capital in the firm when utilized. The deviation for this metric is large with two firms in particular (Skhar Company and Harf Company) which have very large libraries. Each firm had an average of six international software tools and licenses. This average is relatively low. Most of these tools and licenses were purchased from companies such as Microsoft, Oracle and Sun. The average number of meetings among developers was 2.5 times weekly. This indicator reflects one of the organizational mechanisms that is used to exchange knowledge and experiences in the firm. It reflects the aspects of organizational learning and specifically the ability of the firm to leverage its collective learning (Bontis et al., 2002). Since the process of organizational learning supports an organization's capability to take effective action, this indicator is considered as one of the processes components in building and developing structural capital because it involves interaction among developers to reach solutions, ideas, and innovations that solve client and organizational issues.

Results show that the average percentage of documentation is 88 percent. Documentation allows knowledge to be extracted from the person who developed it. By making it independent of that person, it can be reused for future purposes (Hansen et al., 2001). This metric is considered important because it uncovers the ability of the firm to externalize its intellectual assets so that they can be used later for similar projects. The percentage of firms that actually used the earlier documented information was 80 percent. Loermans (2002) argues that the ability of a firm to codify and then reutilize its codified information allows a firm to speed up its renewal process. He cites the case of Skandia Insurance which was able to set-up its office in Mexico in 6 months using previously acquired and documented knowledge, whereas earlier it had expected this task to take 7 years (Loermans, 2002).

According to the CEOs surveyed, the average percentage of bugs in the source code was 0.8 percent which is very small. Although Egyptian developers are efficient from the perspective of their CEOs, this percentage could be biased. To confirm these results, a credible software industry expert was contacted to clarify the data. He indicated that actual mistakes in programming are typically made by new programmers only. When it does happen, it never exceeds 4 percent and it is discovered through the internal auditing process. Furthermore, it is very rare for a software firm to deliver a deficient solution to a client. The percentage of firms using prototype models was 59 percent. The idea of using prototype models involves designing an initial copy of the system and then customizing it to meet the customer needs. This is a typical development process in the software industry. The average percentage of firms that utilize the prototype model internationally is 94 percent which means that the Egyptian firms have not gravitated towards the benefits of prototyping as much as their international counterparts.

The average number of registered software systems is 23 compared to the number of unregistered systems at six. System registration offers legal protection to the structural capital developed by the firm. This indicator also represents the amount of structural capital that is converted to intellectual property which is protected by patent or copyright. These knowledge assets are codified as physical descriptions of certain knowledge by which the company can assert ownership rights (Ashour, 2000). CEOs perception of their firm's speed in implementing their projects averaged 3.89 on a five-point Likert-type scale. This is a relatively high score which reflects the efficiency of the firm in using their IC for achieving their projects. 
TLO $11,4 / 5$

340

There are two other structural capital items that were examined including ISO certification and the Capability Maturity Model (CMM) certification. Table II shows that firms were ISO certified, which is low. In an attempt to justify this, the CEOs reported that ISO certification is costly. Moreover, they mentioned that they are already applying the principles of quality control and improvement without necessitating a formal process. The results of the study also reported that 5.3 percent of firms reached the first level of CMM which is also very low. However, numerous firms pointed out that they are commencing the processes of CMM certification. The Ministry of Communications and Information in Egypt strongly suggests that firms become ISO and CMM certified in an attempt to improve the competitiveness of software development sector. CMM identifies key practices required to improve an organization's software development processes (Osmundson et al., 2003). The CMM consists of five levels of increasing organizational maturity from Level 1 which refers to the lowest-level of capability to Level 5, which refers to the highest-level capability maturity. There were no firms in this study that had higher than Level 1 with most at Level 0 .

Based on the aforementioned results, the following research proposition is suggested.

P2. There is a positive association between the structural capital indicators and organizational performance.

\section{Relational capital indicators}

On an average, each firm's client base consisted of 80 percent of long-term customers. On the one hand, this ratio is considered excellent because it reflects the ability of the firm to retain its customers. It is well known that it is normally easier to sell to the existing customers than to attract new customers. On the other hand, a reliance of existing customers often causes stagnation for innovation. Nevertheless, customer loyalty is a critical component of relational capital. Customer longevity gives an indication of how stable the customer base is (Kennedy, 1998).

The average time from a customer's complaint to solution delivery was almost 3 days. This shows the commitment of the company to solve the customer's problems or complains in a timely manner. During CEO interviews, it was discovered that most firms initially attempt to solve customers' problems by telephone, as a first step of intervention. Most customer complaints involved incompatible software or hardware issues that had nothing to do with the firm's programming itself.

The average number of customers who participated in software testing before final delivery or market release was 9.92 customers per firm. This indicator reflects the flows of learning from customers back to the firm. This indicator represents a path of learning that reinforces the growth of IC stocks in the firm. Bontis (1999) and his colleagues (Bontis et al., 2002) refer to this as feedback learning. The percentage of customers who regularly upgraded or bought a follow-up product was 42 percent. This indicator measures the frequency of repeated orders which is a proxy for customer satisfaction (Kennedy, 1998). The percentage of software launched by the release date was 85 percent. This percentage is considered reasonable given the uncertainty and risks that face the software industry. The percentage of customer complaints was 13.95 percent, which on an average is relatively low. The percentage of positive media 
exposure when the firm was mentioned in the media was 55 percent. The range of responses for this metrics went from 0 to 100 percent.

The average number of connections between a company and experts was 3.52 occasions per month. This value is relatively small which reveals the degree to which the employees leverage the network and talents of industry experts who are at the nexus of the sector. This indicator represents the potential network paths which add knowledge to the IC stocks of the firm. Generally, the use of a network of experts provides the company with specific advantages for conducting its business.

Intellectual

capital

341

The average number of times the media wrote about a company was 8.94 times. This indicator represents the market orientation of the firm and its ability to sustain its image and reputation. On an average, there were 1.68 instances when the firm was represented at a conference which also represents the opportunities the firm can develop its reputation in the marketplace. The average number of memberships in associations and professional organizations (e.g. Egyptian Software Association, The Software Industry Chamber) was 4.13 memberships per firm. Such memberships provide a chance for firms to monitor trends, technical innovations and exporting opportunities. Therefore, the increasing number of memberships reflects the increasing paths of knowledge flows with the marketplace possibly leading to increased opportunities. This indicator represents an active path of knowledge flows to the firms.

The average firm exported to 8.81 countries. This item has particular importance because it often includes an institutional relationship between the company and its clients in export markets. It also implies that firms have a deeper experience with international standards in design and efficiency. According to the World Development Report (1999), export-based companies focus on the investments in knowledge more than companies that emphasize local markets because they have to meet or exceed the global best practices. This indicator also represents a path for knowledge flows to the firms.

Each firm had an average of 1.13 collaborative ventures with the competition. This indicator refers to the acquisition of new knowledge from other firms. Some studies indicate that collaboration between local and foreign firms and travel on the part of executives and technicians are all channels through which knowledge can be transmitted (Navaretti and Tarr, 2000).

Based on the aforementioned results, the following research proposition is suggested.

P3. There is a positive association between the relational capital indicators and organizational performance.

\section{Conclusions}

The present study is the first to investigate the nature of human, structural, and relational capital in Egyptian software firms. The above results revealed that the software firms in Egypt possess many elements of IC and these elements can be, in fact, measured.

The first step for software firms is to develop a knowledge management strategy for each component of IC. A knowledge management strategy contains a series of initiatives that support the firm's different kinds of knowledge assets such as an intellectual property policy to protect certain innovations, a secure documentation of potential business interest (customer lists, price lists, business practices and internal 
TLO

$11,4 / 5$

342

processes) and a set of HR policies to support the recruitment, retention and training of developers. Top management should adopt a policy regarding their stocks of knowledge that would include the exploitation of existing knowledge assets to seize market opportunities without reinventing the wheel.

The indicators used in this study represent a kind of simple list of IC stocks and flows. Regularly tracking of these indicators will help software firms adopt different strategies to acquire, build and exploit their IC. This provides managers with an interesting starting point to answer an important question: what is the level of resources firm should be committed to activate and increase its IC? With the passage of time, the above indicators explain the changes in IC stocks over time. They show how much and in which direction IC is changing, which is helpful for determining the size of the IC in each firm. They also show the deficiencies and threats that companies face. Moreover, measuring the stocks and flows of IC facilities knowledge management processes by introducing guidance aligning those stock and flows (Bontis et al., 2002). The reported approach for measuring the components of IC will help in the institutionalization of standardized measures for benchmarking purposes in software firms. Moreover, it encourages firms to develop customized measures that contribute to the process of establishing tailored IC measures for each firm based on their own vision, strategy, and objectives. Ultimately, IC measurement helps CEOs to realize their competitive position.

\section{Limitation of the study}

The main limitation of this study is that due to the confidentiality of some of the required items in each IC component, the data provided were calculated based on CEOs who self-reported on their own firms. Therefore, measures were not based on raw data. A further limitation is that the study focused only on one country, and one sector and one point at a time. Thus, the ability to generalize is limited to that context.

\section{Future research}

This study is among the first to research IC at the firm level in the Arab region. Some recommendations for future research include the following.

- Empirically test the developed hypotheses which linked IC indicators to organizational performance.

- Collect similar data longitudinally so that hypotheses can be tested by accounting for time lags in changes among IC metrics and organizational performance measures.

- Replicate the study in other sectors within Egypt and explore alternative measures of IC to allow for more generalizations to be made.

- Conduct studies that measure perceptual scales in addition to quantitative measures for the purposes of triangulating results.

- Examine the relationships among IC metrics using structural equation modeling techniques such as PLS, LISREL or AMOS.

- Conduct case studies on successful software companies in Egypt that have achieved a competitive position in the international marketplace. Consider firms in other sectors such as carpet and ceramic industry. 
- Investigate the effects of stocks and flows of IC on the innovation rates within firms in different industries in Egypt.

- Determine whether or not accounting processes or disclosure practices have altered to reflect IC management?

- Examine the stocks of intangible assets such as patents in certain sectors in Egypt and investigate the institutional paths of such patents and what are the barriers behind not leveraging such IC.

- Investigate the role of consultancy firms in creating and transferring useful knowledge to the production and manufacturing sectors of Egypt.

- What are the organizational structures, organizational routines, management practices, leadership styles, and cultures that affect the stocks and flows of IC development in Egypt.

- What are the barriers of harvesting IC in Egyptian Universities and research centers?

- Conduct a study at the national level in Egypt to determine the relative benchmarking of IC development versus the G8.

Although there exists a growing body of literature in the field of IC, much of it is concentrated on the developed world and published in English. One of the outcomes of this paper is to fill that void by offering a fresh new setting for IC measurement in a country that may not be considered as an IC powerhouse by G8 standards, but definitely considers itself as a burgeoning powerhouse in the knowledge era.

\section{References}

Abelson, M.A. and Baysinger, B.D. (1984), "Optimal and dysfunctional turnover: toward an organizational level model”, Academy of Management Review, Vol. 9, pp. 331-41.

Arab Human Development Report (2002), United Nation Development Program, Regional Bureau for Arab States, Jordan (Arabic Version).

Ashour, A.S. (2000), "Knowledge capital management, reinventing management paradigm in the 21st century", Proceedings of the 12th International Conference on Training and Management Development Towards Arab Learning Organization, 25-27 April, Cairo.

Bierly, P. and Chakrabarti, A. (1996), "Generic knowledge strategies in the US pharmaceutical industry”, Strategic Management Journal, Vol. 17, pp. 123-35.

Bontis, N. (1996), "There's a price on your head: managing intellectual capital strategically", Business Quarterly, pp. 40-7, Summer.

Bontis, N. (1998), "Intellectual capital: an exploratory study that develops measures and models", Management Decision, Vol. 36, pp. 63-76.

Bontis, N. (1999), "Managing organizational knowledge by diagnosing intellectual capital: framing and advancing the state of the field", International Journal of Technology Management, Vol. 18 Nos 5-8, pp. 433-62.

Bontis, N. (2001), "Assessing knowledge assets: a review of the models used to measure intellectual capital”, International Journal of Management Reviews, Vol. 3 No. 1, pp. 41-60.

Bontis, N. (2003), "Intellectual capital disclosure in Canadian corporations", Journal of Human Resource Costing and Accounting, Vol. 7 Nos 1/2, pp. 9-20.

Bontis, N. and Fitz-enz, J. (2002), "Intellectual capital ROI: a current map of human capital antecedents and consequent", Journal of Intellectual Capital, Vol. 3 No. 3, pp. 223-47. 
TLO

$11,4 / 5$

\section{4}

Bontis, N., Crossan, M. and Hulland, J. (2002), "Managing an organizational learning system by aligning stocks and flows", Journal of Management Studies, Vol. 39 No. 4, pp. 437-69.

Bontis, N., Dragonetti, N., Jacobsen, K. and Roos, G. (1999), "The knowledge toolbox: a review of the tools available to measure and manage intangible resources", European Management Journal, Vol. 17 No. 4, pp. 391-402.

Bontis, N., Keow, W.C.C. and Richardson, S. (2000), "Intellectual capital and business performance in Malaysian industries", Journal of Intellectual Capital, Vol. 1 No. 1, pp. 85-100.

Brennan, N. and Connell, B. (2000), "Intellectual capital: current issues and policy implication”, Journal of Intellectual Capital, Vol. 1, pp. 206-40.

Brooking, A. (1997), "Management of intellectual capital”, Long Range Planning, Vol. 30, pp. 364-5.

Chase, R.L. (1997), "Knowledge management: benchmarks", Journal of Knowledge Management, Vol. 1, pp. 83-92.

Choo, C.W. and Bontis, N. (2002), The Strategic Management of Intellectual Capital and Organizational Knowledge, Oxford University Press, New York, NY.

Dalton, D.R. and Todor, W.D. (1979), "Turnover turned over: an expanded and positive perspective", Academy Management Review, Vol. 4 No. 2, pp. 225-35.

Dooley, E. (2000), "Intellectual capital in the software industry: an empirical test", $\mathrm{PhD}$ dissertation, College of Business Administration, University of Washington.

Drucker, P. (1993), Post-Capitalist Society, Harper Collins, New York, NY.

Edvinsson, L. and Malone, M.S. (1997), Intellectual Capital: Realizing your Company's True Value by Finding its Hidden Brainpower, Harper Business, New York, NY.

Grant, R.M. (1996), "Toward a knowledge-based theory of the firm", Strategic Management Journal, Vol. 17, pp. 109-22.

Guthrie, J. and Petty, R. (2000), "Intellectual capital: Australian annual reporting practices", Journal of Intellectual Capital, Vol. 1, pp. 241-51.

Hansen, M.T., Nohria, N. and Tiernery, T. (2001), "What your strategy for managing knowledge", Harvard Business Review on Organizational Learning, Harvard Business School Press, Boston.

Harrison, S. and Sullivan, P.H. (2000), "Profiting from intellectual capital: learning from leading companies", Journal of Intellectual Capital, Vol. 1, pp. 33-46.

Hussi, J. and Ahonen, G. (2002), "Managing intangible assets - a question of integration and delicate balance", Journal of Intellectual Capital, Vol. 3, pp. 277-86.

Joia, L.A. (2000), "Measuring intangible corporate assets: linking business strategy with intellectual capital", Journal of Intellectual Capital, Vol. 1, pp. 68-84.

Kaplan, R.S. and Norton, D.P. (1992), "The balanced scorecard-measures that drives performance", Harvard Business Review, Vol. 70, pp. 71-9.

Kennedy, F. (1998), "Intellectual capital in valuing intangible assets", Team Performance Management, Vol. 4, pp. 121-37.

Kogut, B. and Zander, U. (1992), "Knowledge of the firm, combinative capabilities and replication of technology”, Organization Science, Vol. 3, pp. 383-97.

Lapierre, L.M. and McKay (2002), "Managing human capital with competency-based human resources management", in Bontis, N. (Ed.), World Congress of Intellectual Capital Readings, Butterworth-Heinemann-KMCI Press, Boston, MA, pp. 306-37. 
Liebowitz, J. and Suen, C. (2000), "Developing knowledge management metrics for measuring intellectual capital", Journal of Intellectual Capital, Vol. 1, pp. 54-67.

Loermans, J. (2002), "Synergizing the learning organization and knowledge management", Journal of Knowledge Management, Vol. 6 No. 3.

Marques, D. and Garrigos-Simon (2003), "Validating and measuring IC in the biotechnology and telecommunication industries”, Journal of Intellectual Capital, Vol. 4 No. 3, pp. 332-47.

Mason, D. and Pauleen, D.J. (2003), "Perceptions of knowledge management: a qualitative analysis", Journal of Knowledge Management, Vol. 7 No. 4, pp. 38-48.

Nahapiet, J. and Ghoshal, S. (1998), "Social capital, intellectual capital, and the organizational advantage", Academy of Management Review, Vol. 23, pp. 242-66.

Navaretti, G.B. and Tarr, D. (2000), "International knowledge flows and economic performance: a review of the evidence", The World Bank Economic Review, Vol. 14 No. 1, pp. 1-15.

Osmundson, J.S., Michael, J.B., Machniak, M.J. and Grossman, M.A. (2003), “Quality management metrics for software development", Information \& Management, pp. 799-812.

Penrose, E.T. (1959), The Theory of the Growth of the Firm, Basil Blackwell, Oxford.

Petty, R. and Guthrie, J. (2000), "Intellectual capital literature review: measurement, reporting and management", Journal of Intellectual Capital, Vol. 1, pp. 155-76.

Roberts, J. (2002), “Certifications that pay”, Computerworld, No. 1008, pp. 62-4.

Roos, G. and Roos, J. (1997), "Measuring your company's intellectual performance”, Long Rang Planning, Vol. 30, pp. 413-26.

Roos, J., Roos, G., Dragnnetti, N.C. and Edvinsson, L. (1997), Intellectual Capital: Navigating The New Business Landscape, MacMillan, New York, NY.

Spender, J.C. (1996), "Making knowledge the basis of dynamic theory of the firm", Strategic Management Journal, Vol. 17, pp. 45-62.

Stewart, T.A. (1997), Intellectual Capital: The New Wealth of Organizations, Double Day, New York, NY.

Stovel, M. and Bontis, N. (2002), "Voluntary turnover: knowledge management friend or foe?", Journal of Intellectual Capital, Vol. 3 No. 3, pp. 303-22.

Sveiby, K.E. (1997), "The intangible asset monitor", Journal of Human Resource Costing and Accounting, Vol. 2, pp. 73-97.

World Development Report (1999), Knowledge for Development, The World Bank, New York, NY.

Youndt, M.A. (1998), "Human resource management systems, intellectual capital and organizational performance", published $\mathrm{PhD}$ dissertation, Pennsylvania State University.

Zucker, L.G., Darby, M.R. and Brewer, M. (1998), "Intellectual capital and the birth of US biotechnology enterprises”, American Economic Review, Vol. 88, pp. 290-306.

\section{Further reading}

Ashour, A.S. (1997), "Building intellectual and emotional capital of organizations: reinventing human resources development in organizations", Keynote Speech to Conference on training in the Middle East: Achievement and Challenges, El Bahrain.

Bontis, N. (2004), "National intellectual capital index: a United Nations initiative for the Arab region”, Journal of Intellectual Capital, Vol. 5 No. 1, pp. 13-39.

Bornemann, M. et al. (1999), "Holistic measurement of intellectual capital", paper presented at the International Symposium Measuring and Reporting Intellectual Capital: Experiences, Issues, and Prospects, OECD, Amsterdam. 
TLO $11,4 / 5$

Carrol, R. and Tansey, R. (2000), "Intellectual capital in the new internet economy: its measuring, measurement and management for enhancing quality", Journal of Intellectual Capital, Vol. 4, pp. 296-311.

Edvinsson, L. (2000), "Some perspectives on intangibles and intellectual capital", Journal of Intellectual Capital, Vol. 1, pp. 1-10.

Hassen, R. (1995), "Factors correlated with trainees' turnover and human capital investment: suggested model and applied study", PhD dissertation, Faculty of commerce, Alexandria University (in Arabic).

Hock, D.J., Roeding, C.R., Purkert, G., Linder, S.K. and Muller, W.R. (2000), Secrets of Software Success: Management Insights from 100 Software Firms Around the World, Harvard Business School Press, Boston.

Goodman, J.P. with assistance from Rabinovitch D. Huseman, R.C. (1999), Leading With Knowledge: The nature of Competition in the 21st century, Sage Publications, New York, NY.

Johnson, B. and Kleiner, B.H. (1987), "Human asset accounting: where are we today?", International Journal of Manpower, Vol. 8, pp. 3-4.

Nonaka, I. (1994), “A dynamic theory of organizational knowledge”, Organization Science, Vol. 5, pp. 14-37.

O’Regan, P., O’Donnel, D., Kennedy, T., Bontis, N. and Cleary, P. (2001), "Perceptions of intellectual capital: Irish evidence", Journal of Human Resource Costing and Accounting, Vol. 6 No. 2, pp. 29-38.

Ordonez, P. and Pablos, D. (2002), "Evidence of intellectual capital measurement from Asia, Europe and Middle East", Journal of Intellectual Capital, Vol. 3, pp. 277-86.

Pena, I. (2002), "Intellectual capital and business startup success”, Journal of Intellectual Capital, Vol. 2, pp. 180-98.

Reed, K.K. (2000), “The dynamics of intellectual capital”, published $\mathrm{PhD}$ dissertation, University of Connecticut, CT.

Sanches, P., Chaminade, C. and Olea, M. (2000), "Management of intangibles: an attempt to build a theory", Journal of Intellectual Captial, Vol. 1, pp. 312-27.

Sullivan, P.H. (1999), "Profiting from intellectual capital", Journal of Knowledge Management, Vol. 3, pp. 132-42.

Technology Development Program, High-tech Companies in Egypt (1999), The Cabinet Information and Decision Support Center, Cairo, Egypt. 